Eurostudia

\title{
Crossing the Divide
}

Building and Breaking Down Borders through Discourse on

Citizenship and Naturalisation Policy in Germany and the UK, 2000-2010

\section{Helen Williams}

Volume 7, numéro 1-2, 2011

Deutschland und Europa : Grenzen und Grenzgänge(r)

L'Allemagne et l'Europe : frontières et passeurs

URI : https://id.erudit.org/iderudit/1015013ar

DOI : https://doi.org/10.7202/1015013ar

Aller au sommaire du numéro

Éditeur(s)

Le Centre canadien d'études allemandes et européennes

ISSN

1718-8946 (numérique)

Découvrir la revue

Citer cet article

Williams, H. (2011). Crossing the Divide: Building and Breaking Down Borders through Discourse on Citizenship and Naturalisation Policy in Germany and the UK, 2000-2010. Eurostudia, 7(1-2), 87-103. https://doi.org/10.7202/1015013ar

Tous droits réservés @ Le Centre canadien d'études allemandes et européennes, 2012 
Helen Williams

Institute for German Studies, University of Birmingham

7 The past decade has been a period of upheaval for citizenship and naturalisation policy (CNP) in the UK and Germany, with elite discursive shifts reflect1 ing accompanying evolutions in their respective national identities. Germany has gone from insisting that it was not a country of immigration in the 1990s to widespread recognition of its long-resident foreign population and the pressing need to increase integration. The UK, on the other hand, has shifted from elite discursive acceptance of immigration - even, at times, despite public opposition - to increasingly open hostility and continual changes to requirements for naturalisation.

This article examines the shift in perspectives on integration in the UK and Germany and the resulting implications for national identity. Throughout the changes in both countries, there is evidence of conscious construction and alteration of the national narrative that has led to a re-conceptualisation of the borders between "insiders" and "outsiders." The result has been greater inclusion in Germany and greater exclusion in the UK. This article, though drawn from theory-driven research, focuses on describing the changes to CNP in the UK and Germany over the past ten years, examining elite discursive shifts that indicate changing national identities in the face of long-term migration. It ultimately argues that, despite the popularity of convergence literature, ${ }^{1}$ the empirical data supports a growing body of literature indicating continued divergence of British and German CNP. ${ }^{2}$ This article briefly defines key terms used throughout before presenting the United Kingdom and Germany, respectively, as case studies before offering analysis and conclusions about the lack of apparent convergence.

\footnotetext{
1 See Simon Bulmer, "Germany, Britain and the European Union: Convergence through Policy Transfer?," German Politics 16, 1 (2007); Simon Green, Policy Convergence in the UK and Germany (London: Routledge, 2007); Hans Marig and Andreas Wimmer, "Country-Specific or Convergent? A Typology of Immigrant Policies in Western Europe," Journal of International Migration and Integration 1, 2 (2000); Edward Turner and Simon Green, "Understanding Policy Convergence in Britain and Germany," German Politics 16, 1 (2007).

${ }^{2}$ Simon Green, "Divergent Traditions, Converging Responses: Immigration and Integration Policy in the UK and Germany," German Politics 16, 1 (2007); Edward C. Page, "Conclusions," German Politics 16, 1 (2007).
} 


\section{KEY TERMS}

The terms "citizenship" and "nationality" are frequently used interchangeably, though they are separate concepts. When used precisely, citizenship describes not just one's nationality but also the rights and duties accompanying the legal status. ${ }^{3}$ In Germany, politicians consistently employ the term "nationality," but in the UK, usage is far more mixed, due in part to its complicated colonial history and the resulting six main forms of British nationality, including British citizenship. ${ }^{4}$ One could argue that more recent discussions in both countries revolve more around citizenship than nationality, as recent legislation seeks to codify rights and obligations as well as possession of a passport. However, this article's use of the terms reflects the usage in the respective countries.

Discourse in this article is very broadly defined, encompassing the use of written and spoken language, including diction and repetition. Discursive shifts occur when there are changes to popular phrases; previously unacceptable ideas become mainstream; or the words used to frame a debate on contentious issues are modified, causing a change in the focus of the debate.

\section{UNITED KINGDOM}

After a long history of formally unrestrictive policies, recent UK immigration and nationality policies reveal a growing conservative trend, with restrictive changes made to nearly every criterion for naturalisation since 2000 in the UK. ${ }^{5}$

This research does not argue that restrictive discursive shifts have not happened before in the UK: They have occurred several times in post-war British immigration policy, most notably in the aftermath of Enoch Powell's infamous "Rivers of Blood" speech in 1968, which pushed Heath to a more conservative policy. ${ }^{6}$ Such a shift in discourse is again evident in the period in question. After a few decades of carefully constructed scripts and elite shunning of anti-immigrant rhetoric, the discursive shifts between the 2002 and 2009 immigration bills indicate a growing number of mainstream politicians expressing worries about "thresholds," "limits," and lack of integration.

This section analyses the identity discourse evident in responses to external pressures, debates surrounding limits on immigration, the imposition of language requirements, and the Knowledge of Life in the UK Test. Each of these makes clear the shifting discursive scripts and ideas behind British CNP. A common trend is

\footnotetext{
${ }^{3}$ Kay Hailbronner, Country Report: Germany, April ed. (Florence: EUDO Citizenship Observatory, 2010), 1.

${ }^{4}$ For a history of British nationality legislation, see Randall Hansen, Citizenship and Immigration in PostWar Britain: The Institutional Origins of a Multicultural Nation (Oxford: Oxford University Press, 2000).

${ }^{5}$ See Table 1.

${ }^{6}$ Hansen, Citizenship and Immigration, 190.
} 
identifiable throughout: the executive introduces a proposal for change; the proposal is rejected as contrary to British identity as a liberal country of immigration; the plan is dropped; the proposal is reintroduced some time later, passing with little comment.

\section{External pressures}

The governmental agenda shifted during this period in response to pressures on other policy areas and the electoral rewards of a restrictive stance. Discourse during debates in Parliament about the three nationality law bills between 2000 and 2010 indicates the influence of exogenous factors in causing a rapid, unplanned response to events external to CNP. Like many other policy areas during this time period, the most commonly cited exogenous factors were related to the effects of radical Islam. The terrorist attacks in the USA on 11 September 2001 directly occasioned the addition of clauses altering laws regarding deprivation of citizenship. ${ }^{7}$ Even more clearly, the London bombings on 7 July 2005 led to the late introduction of clauses affecting the deprivation of citizenship to a bill that was intended to legislate immigration and asylum, not nationality. ${ }^{8}$ However, both of these cases affected only policy on the deprivation of citizenship; acquisition remained largely untouched by these events.

The UK also faced race riots in 2001 that prompted a debate about integration, especially of non-white minorities. This resulted in a Home Office review and the publication its report on community cohesion. ${ }^{9}$ David Blunkett became Home Secretary around the same time, entering with a pre-set legislative agenda, ${ }^{10}$ and the recommendations from the report simply served to reinforce his proposals.

\section{Discursive shifts}

During the 2002 Nationality, Asylum and Immigration (NIA) Bill debates, limits on immigration were discussed, but permanent settlement were generally confined to Conservative politicians, such as Peter Lilley, who did not receive a great deal of sympathy for their views. ${ }^{11}$ Several chastisements were given during the Immigration, Asylum and Nationality (IAN) Bill (2006) debates for behaviour politicising immigration during the 2005 General Election campaigns. ${ }^{12}$ However, by the time of

\footnotetext{
7 UK Parliament, Parliamentary Debates (Hansard): House of Lords Official Report, 5th Ser., vol. 637, cc. 12, 440-512, 524, 530-554, 565-576, 588-636, 661-678, 844, 689-714, 727-758, 773-814, 963-977, 999-1032, 12331243, 1257-1305, 1322-1388 (London: HMSO, 2002).

8 UK Parliament, Parliamentary Debates (Hansard): House of Commons Official Report on Standing Committee E, 5th Ser., vol. SCE, cc. 001-316 (London: HMSO, 2005).

${ }_{9}$ Ted Cantle (ed.), Community Cohesion: A Report of the Independent Review Team (London: Home Office, 2001).

${ }^{10}$ Helen Williams, "Interview with Senior Home Office Official," Jan. 2010.

${ }^{11}$ UK Parliament, Parliamentary Debates (Hansard): House of Commons Official Report, 5th Ser., vol. 384, cc. 341-436 (London: HMSO, 2002), cc. 378-81.

${ }^{12}$ UK Parliament, Parliamentary Debates (Hansard): House of Commons Official Report on Standing
} 
the Borders, Citizenship and Immigration (BCI) Bill (2009) debates, scripts had shifted. Although actors coupled demands for "limited immigration" with the catchphrase "firm but fair" throughout the decade, ${ }^{13}$ the 2005-2006 and 2009 debates show increasing anti-immigration rhetoric. ${ }^{14}$ Naturalisation was discussed in terms of immigration policy, with ministerial claims of "making migration work for Britain" closely intertwined with increasing the requirements for naturalisation. ${ }^{15}$ There were fewer mentions of the positive contributions of migrants and more expectations placed on them. Lord West, the Labour minister in the House of Lords during the BCI Bill, encapsulates the argument:

We want to encourage those with the right values to become citizens. With rights come responsibilities, and those responsibilities must first be demonstrated, ensuring that the benefits of British citizenship are earned. This is at the heart of the Government's firm-but-fair system. ${ }^{16}$

Nationality acquisition policy remains tied to a discourse of numbers, functioning more as an extension of immigration policy than a policy in its own right in the UK. ${ }^{17}$ Because of its colonial history and its post-colonial involvement with the Commonwealth, the UK has never developed a free-standing citizenship policy. Arguments widely used in the 1960s about strains on resources, lack of space, and panic about numbers have resurfaced, with many of the statements following the general formula of, "I'm not a racist, but the UK simply cannot take on more people." It is increasingly acceptable to say, "The problem is simply one of numbers. There is clearly some limit." 18 The fact that the same arguments were put forth when the national population was around a third lower than today encourages scepticism. ${ }^{19}$

Committee E, cc. 30, 171, 297.

${ }^{13}$ UK Parliament, Parliamentary Debates (Hansard): House of Commons Official Report, c. 379; ibid., c. 885; UK Parliament, Parliamentary Debates (Hansard): House of Lords Official Report, c. 523; UK Parliament, Parliamentary Debates (Hansard): House of Commons Official Report, 5th Ser., vol. 496, cc. 177-257, 801 (London: HMSO, 2009), c. 255; UK Parliament, Parliamentary Debates (Hansard): House of Commons Official Report on Public Bill Committee, 5th Ser., vol. PBC Borders, Citizenship and Immigration Bill, cc. 001-256 (London: HMSO, 2009), c. 156.

${ }^{14}$ UK Parliament, Parliamentary Debates (Hansard): House of Commons Official Report, 5th Ser., vol. 436, cc. 188-275 (London: HMSO, 2005), c. 275; UK Parliament, Parliamentary Debates (Hansard): House of Commons Official Report, 5th Ser., vol. 493, cc.169-241 (London: HMSO, 2009), c. 190, 193, 207; UK Parliament, Parliamentary Debates (Hansard): House of Lords Official Report, 5th Ser., vol. 707, cc. 11281213, WA215-216 (London: HMSO, 2009), c. 1172.

15 UK Parliament, Parliamentary Debates (Hansard): House of Commons Official Report, c. 174; UK Parliament, Parliamentary Debates (Hansard): House of Lords Official Report, c. 1130-1131.

16 UK Parliament, Parliamentary Debates (Hansard): House of Lords Official Report, c. 1130.

17 Ann Dummett, "United Kingdom," in Acquisition and Loss of Nationality: Policies and Trends in 15 European States. Volume 2: Country Analyses, ed. Rainer Bauböck et al. (Amsterdam: Amsterdam University Press, 2006).

18 Peter Lilley, UK Parliament, Parliamentary Debates (Hansard): House of Commons Official Report, c. 378.

${ }_{19}$ Hansen, Citizenship and Immigration, 182-190, 210; Ipsos MORI, "Immigration Poll," (London: Ipsos MORI for The Sun newspaper, 2007). 
With the uptake of citizenship averaging around 150,000 people a year in the years leading up to $2010,{ }^{20}$ the discourse of numbers reflects the delayed influence of policy outcomes, which policy-makers can no longer control. Around a quarter of naturalisations are consistently granted on the basis of marriage; a further quarter of acquisitions are the registrations of minor children on the basis of a parent's nationality. The other roughly fifty per cent of naturalisations are granted on the basis of residence, including both people given refugee status in the UK and highly skilled migrants. ${ }^{21}$

Naturalisations granted on the basis of marriage are difficult for a liberal democracy to regulate. Although the UK has tightened language and integration requirements for spouses, it cannot prevent British citizens from marrying non-Britons. This is a reflection of at least four conventions: everyone has the right to marry whom they choose and that the naturalisation of a foreign spouse is facilitated by marriage. ${ }^{22}$ The recent disregard of international treaties in favour of domestic politics reveals the prioritisation of domestic political concerns over international commitments. The UK also has little power to restrict naturalisations and registrations of minors, and it has been forced to extend gender equality to registration, which had historically been restricted to the mother's nationality. ${ }^{23}$

A deeper look at trends in citizenship uptake based on residence reveals a roughly five-year delay between the sudden increase in asylum seekers in the UK around 2000 and recent applications for citizenship. ${ }^{24}$

The UK experienced a peak in asylum applicants in 2002, at which time the highest numbers of applicants and people granted refugee status were from Iraq, Zimbabwe, Somalia, and Afghanistan. ${ }^{25}$ Five years later, these same people had fulfilled the residency requirements to apply for citizenship, which large numbers did, creating panic about the numbers of people acquiring citizenship, though the UK can reasonably expect these numbers to decrease in the coming years as a reflection of the decrease in refugees after 2002.

\footnotetext{
${ }^{20}$ Philip Danzelman, British Citizenship Statistics: United Kingdom 2008 (Research, Development and Statistics Directorate: Home Office Statistical Bulletin, 2009), 1.

${ }^{21}$ Idem.

22 Council of Europe, European Convention on Nationality, 1997; United Nations, The Universal Declaration of Human Rights, 1948; United Nations, Convention on the Reduction of Statelessness, 1961; United Nations, International Covenant on Civil and Political Rights, 1966.

${ }^{23}$ For an overview of changes prior to the decade here discussed, see Dummett, "United Kingdom," and Hansen, Citizenship and Immigration.

${ }^{24}$ See Figure 1.

${ }^{25}$ David Matz, Rachel Hill, and Tina Heath, "Asylum Statistics: United Kingdom 2000," Home Office Statistical Bulletin 17, 1 (2001): 23-24.
} 


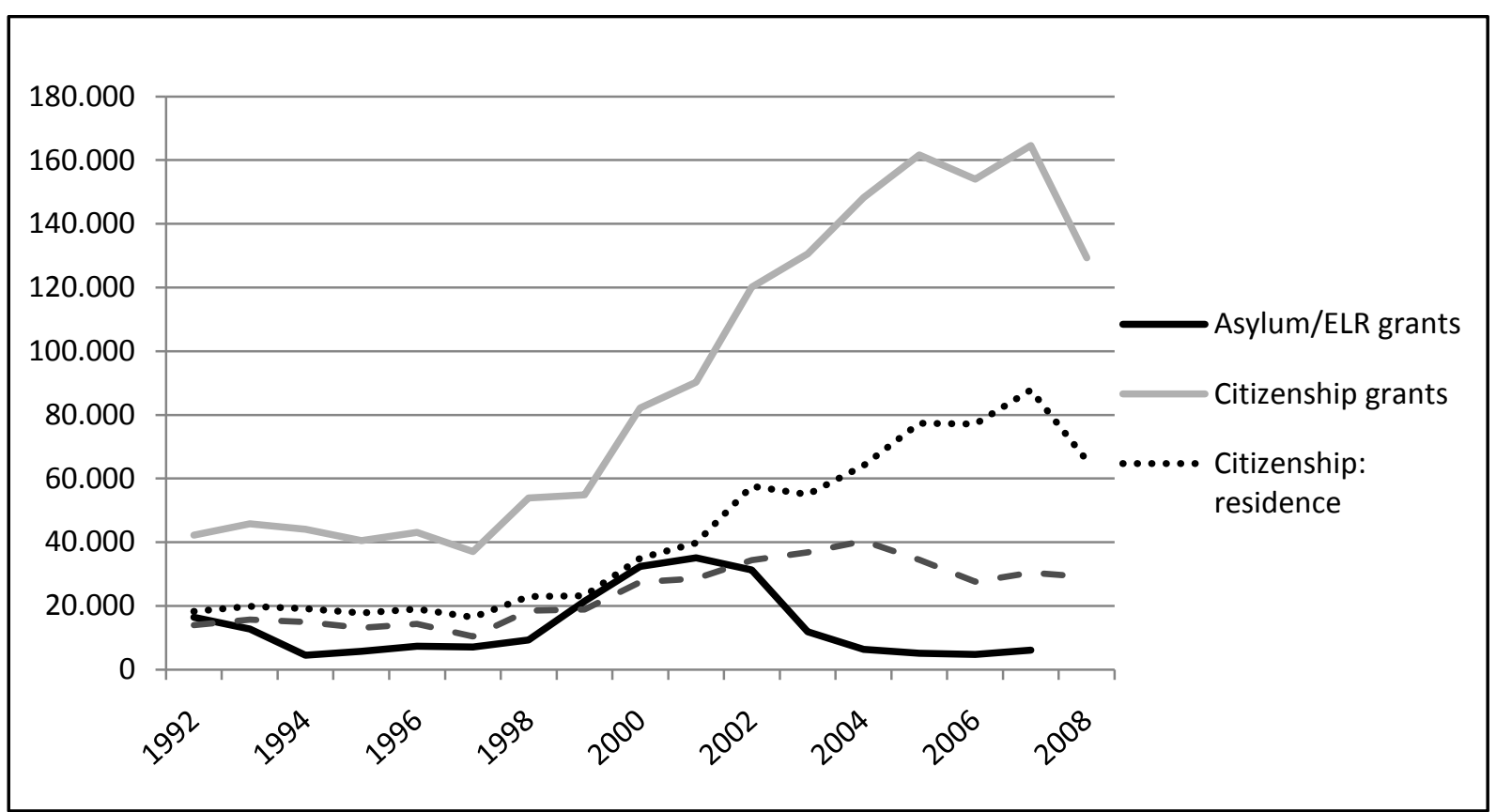

Figure 1. Asylum/Exceptional Leave to Remain (ELR) and Citizenship Grants, UK, 1992-2008.

\section{Change in ideas}

The use of minimum standards of language proficiency as a component of CNP exemplifies changes in ideas as well as behavioural scripts during the past decade. When the government introduced language requirements in the BNA (1981) for naturalisation applications on the basis of residency many organisations and parliamentarians expressed concerns about the potentially discriminatory nature of such a requirement. By 2002, however, the introduction of clauses requiring more formal proof of language ability led to expressions of support and assertions that the previous requirements had been too casual. The extension of these language requirements to spouses of British citizens received intense criticism from some parliamentarians and organisations, though. Some expressed fears that it would interfere with rights of family life; others felt that it would exclude spouses.

Parliamentary debates from the Nationality, Immigration and Asylum (NIA) Bill (2002) indicate conscious discursive construction by the parliamentarians and clearly defined discursive scripts from which few strayed. The direction of the discussions exhibits a lack of acceptance of greater restrictions on spouses, especially the introduction of a formal language requirement. Before 2002, the general assumption was that spouses of British citizens would naturally acquire language skills in the course of marriage, but the government cited evidence that linguistic integration was not as high as it had been assumed or hoped. ${ }^{26}$ Even so, the introduction of a language requirement for spouses of British citizens proved very controversial. Several hours were spent discerning whether it was just or discriminatory to enforce such a requirement.

${ }^{26}$ UK Parliament, Parliamentary Debates (Hansard): House of Lords Official Report, 5th Ser., vol. 636, cc. 1087-1180 (London: HMSO, 2002), c. 1168. 
Some of the legislators still expressed concern about having a language requirement for anyone: "It worries me deeply that there is a requirement to learn English;" 27 "I do not believe that we should impose conditions which are not at present imposed on the citizens of this country." ${ }^{28}$ However, there was a general consensus that economic migrants should be required to prove their proficiency. Discourse surrounding spousal language requirements suggested that it was interfering with British citizens' right to chose a spouse: "I have to say that the suggestion from a Labour Member of Parliament [...] that prospective spouses coming to Britain for arranged marriages should be required to learn English was rightly criticised as being a case of the state dictating who was to marry whom." 29

The new clause passed, however, and by 2009 the politicians no longer questioned the existence of such a requirement but were more concerned that the standard of proficiency was too low. In fact, some politicians congratulated themselves on the positive impact of having enforced the spousal language requirement because of preliminary results indicating that it decreased the social isolation of spouses from non-Western cultures. While those in support of language requirements claimed that they were justified for naturalisation applicants in 2002, the discursive shift by 2009 had led to requirements not only that immigrants must show language proficiency but to proposals to test visa applicants in their home countries before granting entry clearance, akin to the model used in the Netherlands. Such proposals did not draw as much outrage as ten years prior, even though they have the potential to detract significantly from family life and will affect women, the poor, and the least educated the most because of limited access to English courses in their home countries. The Conservative government formally announced the implementation of such requirements starting 29 November 2010. ${ }^{30}$

\section{Integration/naturalisation tests}

Around the period in question, the idea of naturalisation tests became fashionable in Western Europe. Though long used in the USA, Canada and Australia, the Netherlands was the only country in Europe to have a naturalisation/integration test in 2000. Since then, many countries have implemented them, including Denmark, Estonia, Germany, Latvia, Lithuania and the United Kingdom; and France and Belgium are contemplating following suit. This has led to a growing body of literature evaluating the liberal or restrictive nature of these tests. ${ }^{31}$

\footnotetext{
${ }^{27}$ Ibid., c. 445.

${ }^{28}$ Ibid., c. 451.

${ }^{29}$ Ibid., c. 1167.

${ }^{30}$ UK Border Agency, "New English Language Requirement for Partners"

http://www.ukba.homeoffice.gov.uk/sitecontent/newsfragments/26-english-language-partners, accessed 10.09.2010.

${ }^{31}$ See Rainer Bauböck and Christian Joppke (eds.), "How Liberal Are Citizenship Tests?," EUDO Citizenship Observatory, EUI Working Paper RSCAS 2010/41; especially the contribution by Sergio
} 
The Knowledge of Life in the UK Test was originally brought in as a naturalisation exam before being applied as a requirement for settlement status. Its introduction is a clear example of the technique mentioned above - introducing a change, receiving criticism, withdrawing it, and reintroducing the same change at a later date. As Table 1 shows, this test was not a requirement at the starting point in 2000. It was brought in after much heated debate in the 2002 Nationality, Immigration and Asylum Act. Major objections were made on the grounds of it being discriminatory against non-EU nationals. ${ }^{32}$ The government convinced the parliamentarians that it was not discriminatory, however, on the grounds that the test was not required for visa applications but only for naturalisation, and EU nationals were subject to the same criteria as non-EU nationals in the naturalisation process. ${ }^{33}$ Several of the objecting Members subsequently withdrew their objections on the grounds of these reassurances.

In 2006, the government changed the point of application of the Knowledge of Life in the UK Test, ${ }^{34}$ making it compulsory for anyone applying for settlement in the UK. ${ }^{35}$ Such a requirement was directly contrary to the assurances given during the 2002 debates that the test was not discriminatory against non-EU nationals, as EU nationals do not need to apply for settlement status in the UK because of their right to live in any EU member state. The UK government continued with this tactic in 2009, presenting the possibility of using the Knowledge of Life in the UK Test as a hurdle for settlement and a second exam focused on civics and history for applicants for naturalisation. ${ }^{36}$ This was justified on the grounds that the Knowledge of Life Test examines applicants on topics that are important to settlement, while a civics exam would make sure that applicants understood the political system and how to exercise the rights of citizenship, such as voting, to which applicants had not previously had access.

\section{Summary}

This brief overview indicates the breadth and depth of changes in nationality acquisition and the connected discursive shifts in the UK between 2000 and 2010. The process of change in the UK is particularly interesting because it follows a clear pattern of testing an idea, withdrawing it after a negative reaction, then subsequently re-introducing the idea successfully when the initial aversion has worn off. This

\footnotetext{
Carrera and Elspeth Guild, "Are Integration Tests Liberal? The "Universalistic Liberal Democratic Principles" as Illiberal Exceptionalism," 29-34.

32 UK Parliament, Parliamentary Debates (Hansard): House of Commons Official Report, 5th Ser., vol. 388, cc. 440-554 (London: HMSO, 2002).

${ }^{33}$ UK Parliament, Parliamentary Debates (Hansard): House of Commons Official Report on Select Committee E, 5th Ser., vol. SCE cc. 001-064 (London: HMSO, 2002), c. 020.

${ }^{34}$ UK Parliament, "Immigration, Asylum and Nationality Act," (2006).

http://www.opsi.gov.uk/acts/acts2006/pdf/ukpga_20060013_en.pdf (accessed 10 Aug. 2009).

${ }^{35}$ See Table 1.

${ }^{36}$ UK Border Agency, "Earning the Right to Stay: A New Points Test for Citizenship," (2009), 6.
} 
method becomes apparent through an overview of government publications, documentation of public and parliamentary response, and parliamentary debates.

The discursive shift between 2000 and 2010 indicates movement towards a more restrictive position. Despite expressions of concern from a wide array of immigrants' rights associations, the UK government lengthened the residence requirement for labour migrants and those on the protected route, for whom the path to citizenship could now take eight years from the time of acquisition of a qualifying residence status. $^{37}$ This drew harsh criticism especially from the UN High Commissioner for Refugees, whose office has long demanded that the path to citizenship for recognised refugees should take no more than five years. ${ }^{38}$ The domestic political rewards for a restrictive citizenship policy have clearly outweighed the international punishment for behaviour in violation of treaties of which the UK is a signatory.

\section{GERMANY}

Germany, on the other hand, has moved from a very restrictive citizenship regime for much of the twentieth century to a more liberal regime that attempts to fulfil treaty obligations and to further integration. After decades of naturalisation being the exception rather than the rule, even for second- and third-generation immigrants, Germany now officially encourages naturalisation, and policies are intended to increase integration and naturalisation rates. Although some of the German policy changes have been similar to the UK, others now make Germany more liberal than the UK. ${ }^{39}$ It is Germany's discourse, however, that presents the strongest evidence of the liberalising shift. From widespread statements that Germany was not a country of immigration in 2000 to open acceptance that it is a country of immigration in 2010, this reflects a broader discursive shift. Politicians are now punished for politicising integration, and there is a broad consensus in favour of easing naturalisation.

Even in the first years after the landmark changes to the Staatsangehörigkeitsgesetz (StAG) came into effect on 1 January 2000, both academic and public discourse continued to focus on the xenophobic, ethno-cultural German identity. Yet the past decade shows evidence of discursive, legislative and administrative shifts that commentators ten years ago largely dismissed as impossible. This section examines the historical influences on German discourse and policy, the politicisation of immigration, the roles of public opinion and the media, and finally the shift towards positive public discussion of integration and greater "constitutional patriotism" replacing the ethno-cultural model.

\footnotetext{
${ }^{37}$ See Table 1.

${ }^{38} \mathrm{UNHCR}$, Borders, Citizenship and Immigration Bill: Parliamentary Briefing, House of Commons Second Reading (London: United Nations, 2009), 2.

${ }^{39}$ See Table 1.
} 


\section{Discursive scripts}

Discursive scripts play a very important role in the construction of the perceived reality in Germany. Shifts in scripts have accompanied the change in national understanding of what it means to be German in the slow transformation from an inherited characteristic to a community that rallies around a common constitution and set of accepted societal values. The path of the Immigration Act from 2001 to 2004 and the Integration Summits of the Merkel chancellorship provide excellent examples of changing scripts. The rate of changing norms was different on the left than the right, and each merits its own discussion.

SPD discursive scripts showed the greatest period of change before the introduction of the Immigration Act in 2001, but the debates between 2001 and 2004 show evidence of the solidification of the new scripts. In 1998, Minister of the Interior Otto Schily famously said, "The capacity for immigration in Germany has been exceeded," 40 a quote that CDU/CSU politicians cited during the 2002 debates. ${ }^{41}$ However, in 2002, he was much more careful about his phrasing: "The limitation of immigration, taking into account the capacity for absorption and the willingness of the Federal Republic of Germany, must be the goal of this law." ${ }^{42}$ With this he implied that the threshold had not been exceeded but simply that the absorptive capacity needed to be recalled. At the same time, he clearly stated that immigration must continue, citing the report of the Müller Commission: "Managed migration of skilled workers is, therefore, very much in the interest of our national economy and thus of the entire country." 43

The years between 2000 and 2005 were an important transitional period in elite discourse because it was during this time that most of the politicians agreed to stop consciously politicising immigration-related policies in recognition of the great damage inflicted for minor electoral gains. Before this tacit - and sometime explicit agreement, several politicians expressed frustration at the acceptance of the need for a coherent Immigration Act and comprehensive action on integration measures when speaking privately accompanied by outright rejection and insistence on an irreconcilable gulf between the parties when speaking publicly about the policy options. ${ }^{44}$

\footnotetext{
40 "Die Grenze der Belastbarkeit Deutschlands durch Zuwanderung ist überschritten," in "Der Rechtsextremismus ist die größte Gefahr, " Der Tagesspiegel, 15.11.1998, 4.

41 Deutscher Bundestag, "Deutscher Bundestag: Stenographischer Bericht," Verhandlungen des Deutschen Bundestages BT Drs. 14/222, 1 Mar (2002): c. 22031.

42 "Die Begrenzung der Zuwanderung unter Berücksichtigung der Aufnahmefähigkeit und der Bereitschaft der Bundesrepublik Deutschland muss das Ziel des Gesetzes sein." Otto Schily, ibid., c. 22045.

43 "Eine gesteuerte Zuwanderung qualifizierter Fachkräfte liegt daher durchaus im Interesse unserer Volkswirtschaft und damit des gesamten Landes," ibid.

${ }^{44}$ Kay Hailbronner disagrees that pleas for non-politicisation pay anything more than rhetorical lipservice (Hailbronner, Country Report: Germany, 26).
} 
Sigmar Gabriel named this a "Vieraugengesellschaft," ${ }^{45}$ underscoring the discrepancies between scripts employed for public consumption and the content of discussions behind closed doors. ${ }^{46}$

Although scripts were changing, the 2001-2002 parliamentary speeches are filled with speeches by CDU/CSU politicians decrying Germany's status as a country of immigration and rejecting multiculturalism of any definition. In this context, the perceived meaning of integration varied widely, from visions of full assimilation to the harmonious parallel existence of multiple cultures. Christian Union members generally agreed that Germany was not a country of immigration.

However, Chancellor Merkel laid out a new agenda for integration when the CDU/CSU returned to power in 2005, signalling a change and ushering in a series of integration summits with representatives from a wide variety of NGOs, immigrant groups and practitioners. Her leadership seemed to indicate a deviation from the traditional Christian Democratic understanding of integration. However, with the stark drop in popularity of the black-yellow coalition following the September 2009 elections and the euro crisis as well as the public discussion ignited by the publication of controversial Federal Bank chairman Thilo Sarazzin's book in summer 2010, the Christian Union appeared poised for a shift to the right. Some argue this is exactly what happened when Angela Merkel announced on 16 Oct 2010 that "multiculturalism has absolutely failed." 47 In itself, this statement seems to constitute a return to the Christian Union Parties' adherence to German culture as a leading culture and rejection of multiculturalism as the model for integration. However, it could also be interpreted as a response to the intra-party rebellion, which has shown more politicians criticising the centrist shift under Merkel, blaming the party for leaving the right wing open by abandoning its conservative core. ${ }^{48}$ After a summer focused on party unity, Merkel's statement could simply be an excellent example of Gabriel's disjuncture between scripts created for public - or party - consumption and those behind closed doors during policy negotiations. What the situation certainly indicates is that this discursive script is still under negotiation.

\section{Change in ideas}

Changes in ideas certainly play a role in the institutional change of CNP in Germany. In interviews, multiple parliamentarians mentioned the Netherlands as a country to whom Germany looked for ideas to promote integration. ${ }^{49}$ The FDP in particular considered the Dutch model at the beginning of the 2000s as "very appeal-

\footnotetext{
${ }^{45}$ Lit., a "four-eyed society," the closest English idiomatic equivalent is "behind closed doors."

46 Deutscher Bundesrat, "Bundesrat: Stenographischer Bericht," Verhandlungen des Deutschen Bundesrates BR Drs. 14/774, (2002): c. 143.

47 "Integration: Merkel erklärt Multikulti für gescheitert," Spiegel Online, 16.10.2010.

${ }^{48}$ Daniela Vates, “Weniger Konservatismus wagen," Berliner Zeitung, 13.01.2010.

${ }^{49}$ Helen Williams, "Interview with Dr. Max Stadler, FDP," 23 Apr. 2009; Helen Williams, "Interview with Stephan Mayer," 7 May 2009.
} 
ing, but Germany wasn't ready." ${ }^{50}$ However, Dutch policies afterwards took a more restrictive direction, and "in the end, Germany chose its own path." 51

Even the long-held idea that naturalisation should be the end-point of the integration process is beginning to break down. "While the ruling Social Democratic Party in 1999 considered the acquisition of German nationality to be an essential instrument in achieving integration, the opposition Christian Democratic Parties (CDU/CSU) argued that naturalisation should complete the process of integration rather than pave the way towards it." 52

\section{Integration/naturalisation tests}

Germany's integration test was announced with the EU Directives Implementation $\mathrm{Act}^{53}$ and implemented on 5 August 2008 to allow time for the test's development. ${ }^{54}$ Its form exemplifies the mixed character of integration tests. On the one hand, the creation of a federally designed exam finally standardised the naturalisation process, which had previously been different in each state, leading to vastly different naturalisation rates and requirements. On the other hand, there are always arguments that such exams raise the bar for naturalisation. However, Germany's use of integration tests appears not to act as an instrument of exclusion, as initial figures indicate a ninety-nine per cent pass rate, ${ }^{55}$ far higher than the UK's seventy-one per cent pass rate for its Life in the UK Test. ${ }^{56}$ Whether these changes are liberal or restrictive, the exchange of new ideas about integration and naturalisation tests has certainly resulted in the institutional change of CNP in both Germany and the UK.

\section{National identity}

Although discussions in Germany have revolved around citizenship as the endpoint of integration - a reward for taking on German values - German identity discourse has shifted substantially in the past ten years. After successful right-wing campaigns against foreigners in the 1990s, parties who have subsequently strayed from the newly established discursive scripts have been punished rather than rewarded by voters. ${ }^{57}$ From Brubaker's famous prophecy that Germany's policy process was too path dependent to be able to institute an ius soli (birthright) system

\footnotetext{
${ }^{50}$ Williams, "Interview with Dr. Max Stadler, FDP."

${ }^{51}$ Williams, "Interview with Stephan Mayer."

${ }^{52}$ Hailbronner, Country Report: Germany, 19.

${ }^{53}$ Bundesgesetzblatt, "EU-Richtlinienumsetzungsgesetz," BGBl I, 28.08.2007.

${ }^{54}$ Bundesgesetzblatt, "Verordnung zu Einbürgerungstest und Einbürgerungskurs (Einbürgerungstestverordnung)," BGBl I, 05.08.2008.

${ }^{55}$ Christoph Wöhrle, "Deutschland: Einbürgerungstest wird fast immer bestanden," Migration und Bevölkerung 1 (2009).

${ }^{56}$ Helena Wray, “United Kingdom: 29.1 Percent of Migrants Taking the Citizenship Test Fail," EUDO Citizenship Observatory, accessed 01.09.2010, http://eudo-citizenship.eu/citizenship-news/314-uk-291percent-of-migrants-taking-the-citizenship-test-fail-.

${ }^{57}$ Karl-Heinz Meier-Braun, Deutschland, Einwanderungsland (Frankfurt am Main: Suhrkamp, 2002), 102.
} 
of citizenship ${ }^{58}$ to a system more liberal than France and widely accepted by the German public, ${ }^{59}$ discourse surrounding national identity is strongly indicative of dramatic change.

Changes in ideas about the German national identity have resulted directly in changes to CNP. Once an institution that focused on descent as the main criterion for nationality - for the many reasons discussed above - the growth of Germany's nonGerman population and status as a de facto country of immigration forced a national debate about identity. Two competing conceptions have emerged: the more conservative view that one can only hold loyalties to one country, a model that rejects multiple nationality; and a "republican" or "constitutional patriotic" concept, which rallies around compliance with the rule of law and respect for the principles of the Basic Law. ${ }^{60}$ The widespread, continuing debates about terms like "integration" and Leitkultur show that a new discursive equilibrium has not yet been reached. ${ }^{61}$

The changing national identity is reflected most starkly by the dividing line of the Nationality Act (1999). Hailbronner writes,

Since 1 January 2000, naturalisation and acquisition of German nationality is considered as being in the public interest of Germany rather than as an unavoidable fact. This change in nationality law also reflects a substantial change in the perception of migration. The original assumption that the migrant workers recruited in the early 1970s would return eventually to their home countries has been abandoned. ${ }^{62}$

Changes in discourse about whether Germany is, in fact, a country of migration have accompanied this. The ethnocentric discursive script began to break down in the 1990s, with the early 2000s acting as a transition period during which acceptance of Germany's status as a country of immigration was still limited. By the time Angela Merkel came into office in 2005, however, the debate was largely settled, and even the CDU and much of the CSU openly admitted that Germany is a country of immigration. ${ }^{63}$ As chancellor, Merkel made a national discussion of integration a priority, inviting many different migrant interest groups, including the major Turkish societies, to a series of Integration Summits, where a National Integration Plan was created. Although the summits have been subject to criticism for producing little in the way of concrete changes, they still mark a turning point in German CNP. As Reimman points out, "[...] the very idea behind the events was revolutionary. It was

\footnotetext{
${ }_{58}$ Rogers Brubaker, Citizenship and Nationhood in France and Germany (Cambridge, MA: Harvard University Press, 1992), 185.

${ }_{59}$ Dietrich Thränhardt, "Include or Exclude: Discourses on Immigration in Germany," Journal of International Migration and Integration 3, 3-4 (2002): 359.

${ }^{60}$ Hailbronner, Country Report: Germany, 25-26.

${ }^{61}$ Ibid., 26.

62 Ibid., 17.

${ }^{63}$ Karl Forster, "Heiner Geißler im Gespräch: "Man muss vor Menschen keine Angst haben"," Süddeutsche Zeitung, 11.12.2004; Anna Reimann, "Vor dem Gipfel: Integratives Kuscheln," Spiegel Online, 12.07.2006.
} 
the first time that the federal government officially sat down with migrants and Muslims." 64

\section{Integration starts at home}

By 2005, 18.9 per cent of the population in Germany had an immigrant background, rising to close to 40 per cent in Germany's large cities. ${ }^{65}$ Amongst those under the age of 15 , the proportion was 30 per cent and almost 45 per cent of those in large cities. ${ }^{66}$ Such statistics have become common knowledge in much of Germany and, rather than fuelling arguments that the country was too full, they have begun to support arguments that a greater effort must be made by the Germans to facilitate integration.

The new catchphrase in Germany has become "integration starts at home," 67 emphasising the importance of the local community. ${ }^{68}$ This reflects the growing consensus that federal legislation can only set the framework for integration, while the local institutions must take charge of the actuality of policy administration. ${ }^{69}$ Federal Chancellor Angela Merkel has recognised the need for greater dialogue about integration, convening a series of integration summits to which practitioners, immigrants, and various interest groups were invited to discuss the state of integration and how to improve it. Although these summits have drawn criticism and have suffered from the decisions of key groups to boycott them, they still symbolise a shift towards greater form of inclusion and consultation, a radical step in German policy. Following the federal example, local authorities have sought the opinions and suggestions of immigrants and minorities more in the policy-making process. ${ }^{70}$ People of migrant origin are spoken of now as "policy partners," reflective of a paradigmatic change at both the local and national levels. ${ }^{71}$ Some cities have begun openly recruiting people with migration origin for public service jobs. ${ }^{72}$

\footnotetext{
${ }^{64}$ Anna Reimann, "Integrationspolitik: Die Entdeckung der Einwanderer,"Spiegel Online, 30.12.2009.

${ }^{65}$ Statistisches Bundesamt Deutschland, Mikrozensus 2005 (Wiesbaden: Bundesregierung Deutschland, 2006).

66 “7. Bericht der Beauftragten der Bundesregierung für Migration, Flüchtlinge und Integration über die Lage der Ausländerinnen und Ausländer in Deutschland" (Berlin: Die Beauftragte der Bundesregierung für Migration, Flüchtlinge und Integration, 2007).

67 "Integration findet vor Ort statt."

${ }_{68}$ Bundesregierung Deutschland, Nationaler Integrationsplan: Neue Wege - Neue Chancen, July 2007 (Berlin: Presse- und Informationsamt der Bundesregierung, 2007).

69 Hartmut Häußermann and Andreas Kapphan, "Integrationspolitik der Städte - Ein Paradigmenwechsel," in Migrationsreport 2008, ed. Michael Bommes and Marianne Krüger-Potratz (Frankfurt: Campus Verlag, 2008), 15-16.

${ }^{70}$ Lena Wundenberg, "Bilanz der bisherigen Integrationsgipfel: Ernüchterung, wenn es ins Detail geht," Tagesschau, 06 Nov. 2008.

${ }^{71}$ Häußermann and Kapphan, "Integrationspolitik der Städte," 23.

72 Ibid., 25."
} 


\section{Summary}

Germany has learned in recent decades that citizenship policy, while not a routine issue like the annual budget, cannot be ignored because countries must address the situation of the millions of foreigners living within their borders, as it has become clear that they are not temporary migrants looking to leave soon. As a consequence, it has realised the necessity of higher levels of naturalisation. ${ }^{73}$ Higher levels of naturalisation cannot be realised simply through legal and administrative changes, however: uptake of German citizenship continued at levels seen as disappointing after an initial surge in response to the 1999 changes. Uptake must be encouraged through greater public acceptance, higher incentives for naturalisation, and a discursive shift from an ethno-cultural national identity to a more civic identity.

Both "foreigners" and Germans seem to have a tacit understanding that the acquisition of German citizenship is not simply a membership to the state and all its civic responsibilities but also indicative of a cultural understanding. ${ }^{74}$ This cultural membership seems to be a form of expression of loyalty to the German state, a central theme in many of the policy discourses in the 1990s in Germany. ${ }^{75}$ German integration efforts have focused increasingly on linguistic unity whilst moving away from ethnic identity. With this has also come a growing emphasis on constitutional patriotism similar to the American model: creating a national identity through loyalty to the political institutions and democratic ideals rather than through a common ethnic history. Where integration in Germany previously meant something closer to assimilation, requiring the immigrant to lose any previous identity and become virtually undistinguishable from ethnic Germans, discourse in Germany has sought to re-define this term. The National Integration Plan proposes that "Integration means integration into the social, economic, intellectual, cultural and legal fabric of the host country without giving up one's own cultural identity." 76 For the first time, there is widespread discussion of reciprocal adaptation in place of an expectation that immigrants must make all of the changes. ${ }^{77}$

\section{CONCLUSIONS}

The British and German cases show several common responses and the impact of popular ideas during the past decade: both are renegotiating their national identities; both have instituted integration/naturalisation tests and citizenship ceremonies; and both have formalised language requirements. However, these seemingly similar changes do not indicate a convergence of policy trajectories. The methods of policy

\footnotetext{
${ }^{73}$ Simon Green, The Politics of Exclusion: Institutions and Immigration Policy in Contemporary Germany (Manchester: Manchester University Press, 2004), 142.

${ }^{74}$ Brubaker, Citizenship and Nationhood in France and Germany, 178.

${ }^{75}$ Green, The Politics of Exclusion, 104.

${ }^{76}$ Bundesregierung Deutschland, 127.

${ }_{77}$ Ibid.; Häußermann and Kapphan, “Integrationspolitik der Städte," 18.
} 
implementation and the intentions of the changes have led to divergent outputs and outcomes. While German rhetoric has grown more inclusive, British has grown more exclusive. The initial statistics for the German naturalisation exam indicate a 99 per cent pass rate, while the Knowledge of Life in the UK test pass rate is less than 75 per cent, with results varying widely between different ethnicities. Immigrants are required to pay for citizenship ceremonies in the UK, and acquiring British nationality is nearly four times more expensive than German nationality, acting as an effective deterrent to many. The length of time required to acquire nationality is now nearly identical.

Despite the similar current requirements in the two countries, the evidence does not seem to point towards convergence; rather, a comparison indicates that perhaps Germany and the UK have crossed paths on trajectories headed in opposite directions, a finding contrary to convergence studies in many other policy areas. However, this supports the conclusions of several policy experts in a special issue on policy convergence in the UK and Germany. ${ }^{78}$ Though there is evidence of policy sharing with regards to popular ideas like naturalisation ceremonies and swearing of oaths according to a more American or Dutch model, in terms of requirements likely to affect the ability of the foreigners to naturalise, Germany is in many ways now more liberal than the UK, which has tightened the criteria for naturalisation to such an extent that it is only more liberal than Germany in its widespread acceptance of multiple nationality. Yet the UK retains its reputation for liberal policy in much of the national discourse, while Germany continues with its post-war pattern of selfcriticism.

While Britain seems to be reviving the sentiments of the 1960s, indicating a discursive shift towards exclusion and greater assimilation rather than reciprocal integration, Germany seems to be shaking off its ethno-cultural model and building a linguistic and constitutional patriotism. Germany has now largely dropped slogans like "the boat is full," while British discourse increasingly cites overburdening of the infrastructure and welfare system. Anti-immigrant discourse is becoming more acceptable in the UK at all levels, with restrictive immigration policies featuring in the campaign manifestos of the major political parties and in parliamentary debates without backlash and even with reward, while attempts to politicise immigration and integration in Germany have increasingly resulted in punishment of the responsible actors. For the time being, it appears that British identity discourse will continue to accept certain levels of antiimmigrant speech, and policies will continue in a restrictive direction; on the other hand, German discourse appears to be growing more liberal and more stable, and the country appears to be establishing a new discursive norm that is more inclusive and exhibits more elements of reciprocal integration.

Helen Williams mrshelenmwilliams@gmail.com

${ }^{78}$ German Politics 16, 1 (2007). 
Table 1. Comparative table of naturalisation requirements, 2000-2010.

\begin{tabular}{|c|c|c|c|c|c|c|c|}
\hline & \multicolumn{4}{|c|}{ UK } & \multicolumn{3}{|c|}{ Germany } \\
\hline Criterion & 2000 & 2002 & 2006 & 2009 & 2000 & 2005 & 2007 \\
\hline $\begin{array}{l}\text { Good } \\
\text { character }\end{array}$ & Yes & Yes & Yes & Yes & $\begin{array}{l}\text { Fines up to } 180 \\
\text { days wages, } \\
\text { prison } \\
\text { sentences up to } \\
6 \text { months }\end{array}$ & $\begin{array}{l}\text { Fines up to } 180 \\
\text { days wages, } \\
\text { prison } \\
\text { sentences up to } \\
6 \text { months }\end{array}$ & $\begin{array}{l}\text { Fines up to } 90 \\
\text { days wages, } \\
\text { prison } \\
\text { sentences up } \\
\text { to } 3 \text { months }\end{array}$ \\
\hline Language & $\begin{array}{l}\text { Casual, } \\
\text { none for } \\
\text { spouses }\end{array}$ & $\begin{array}{l}\text { Yes, } \\
\text { including } \\
\text { spouses }\end{array}$ & Yes & Yes & Yes/Not & Yes/Not & Yes, CEFR B1 \\
\hline $\begin{array}{l}\text { Citizenship } \\
\text { oath/pledge }\end{array}$ & Oath & $\begin{array}{l}\text { New oath } \\
\text { and pledge }\end{array}$ & $\begin{array}{l}\text { Oath and } \\
\text { pledge }\end{array}$ & $\begin{array}{l}\text { Oath and } \\
\text { pledge }\end{array}$ & No & No & Yes \\
\hline $\begin{array}{l}\text { Citizenship } \\
\text { ceremony }\end{array}$ & No & Yes & Yes & Yes & No & No & Yes \\
\hline $\begin{array}{l}\text { Integration } \\
\text { /naturalisa- } \\
\text { tion test }\end{array}$ & No & Yes & $\begin{array}{l}\text { Yes, for } \\
\text { settlement }\end{array}$ & $\begin{array}{l}\text { Yes, } \\
\text { possible } \\
\text { second test }\end{array}$ & No & $\begin{array}{l}\text { Yes, law and } \\
\text { society test }\end{array}$ & $\begin{array}{l}\text { Yes, plus } \\
\text { naturalisation } \\
\text { test }\end{array}$ \\
\hline Cost & $\begin{array}{l}\text { Approx. } \\
£ 150\end{array}$ & $\begin{array}{l}\text { Approx. } \\
£ 150\end{array}$ & $\begin{array}{l}\text { Approx. } \\
£ 575\end{array}$ & $\begin{array}{l}\text { Approx. } \\
£ 800\end{array}$ & $\begin{array}{l}\text { 500DM (adult) } \\
\text { /100DM (child) } \\
\text { /reductions } \\
\text { possible }\end{array}$ & $\begin{array}{l}€ 255 \\
\text { (adult)/€51 } \\
\text { (child)/ } \\
\text { reductions } \\
\text { possible }\end{array}$ & $\begin{array}{l}255 \\
\text { (adult)/€51 } \\
\text { (child)/ } \\
\text { reductions } \\
\text { possible }\end{array}$ \\
\hline $\begin{array}{l}\text { Length of } \\
\text { residence }\end{array}$ & $\begin{array}{l}3 \text { yrs } \\
\text { (spouses), } \\
5 \text { yrs } \\
\text { (residence) }\end{array}$ & $\begin{array}{l}3 \text { yrs } \\
\text { (spouses), } \\
5 \text { yrs } \\
\text { (residence) }\end{array}$ & $\begin{array}{l}3 \text { yrs } \\
\text { (spouses), } \\
5 \text { yrs } \\
\text { (residence) }\end{array}$ & $\begin{array}{l}\text { 3-5 yrs } \\
\text { (spouses), } \\
\text { 6-8 yrs } \\
\text { (residence) }\end{array}$ & 8 years & 8 years $/ 7$ years* & $\begin{array}{l}8 \text { Years } / 7 \\
\text { years } * 6 \text { years }\end{array}$ \\
\hline $\begin{array}{l}\text { Absences } \\
\text { from } \\
\text { country }\end{array}$ & $\begin{array}{l}\text { Avg. } 90 \\
\text { days/yr, } 90 \\
\text { days in } \\
\text { final year }\end{array}$ & $\begin{array}{l}\text { Avg. } 90 \\
\text { days/yr, } 90 \\
\text { days in } \\
\text { final year }\end{array}$ & $\begin{array}{l}\text { Avg. } 90 \\
\text { days/yr, } 90 \\
\text { days in } \\
\text { final year }\end{array}$ & $\begin{array}{l}\text { Absolute } \\
90 \text { days/yr }\end{array}$ & Up to 6 months & Up to 6 months & Up to 6 months \\
\hline $\begin{array}{l}\text { Activity } \\
\text { (UK)/ } \\
\text { Options- } \\
\text { modell } \\
\text { (DE) }\end{array}$ & No & No & No & Yes & Yes & Yes & Yes \\
\hline
\end{tabular}

Restrictive changes indicated in bold. Liberal changes indicated in italics.

* Upon successful completion of integration course. ** In cases of "extraordinary integration," especially linguistic.

† Proof of sufficient German knowledge required for naturalisation by right (Anspruch) but not for naturalisation by discretion (Ermessen). 